\title{
PERAN SUPERVISI AKADEMIK TERHADAP PENINGKATAN KEMAMPUAN MERANCANG RENCANA PELAKSANAAN PEMBELAJARAN GURU SMAN I TANJUNG JABUNG BARAT TAHUN PELAJARAN 2018/2019
}

\author{
KHAIRIL ANAM \\ SMA Negeri 1 Tanjung Jabung Barat Provinsi Jambi \\ khairilanamdapodik@gmail.com
}

\begin{abstract}
ABSTRAK
Penelitian ini merupakan Penelitian Tindakan Sekolah (PTS) yang bertujuan untuk mengetahui peran suvervisi akademik terhadap peningkatan kemampuan merancang Rencana Pelaksanaan Pembelajaran (RPP) bagi guru SMA Negeri 1 Tanjung Jabung Barat Tahun Pelajaran 2018/2019. Dalam penelitian ini, kemampuan guru yang akan difokuskan adalah dalam merancang rencana pelaksanaan pembelajaran (RPP). Penelitian ini dilakukan di SMA Negeri 1 Tanjung Jabung Barat, Provinsi Jambi. Adapun subjek penelitian dalam PTS ini adalah guru yang mengajar di SMA Negeri 1 Tanjung Jabung Barat, dengan sampel 10 guru. Terdapat 7 aspek yang diamati dalam merancang rencana pelaksanaan pembelajaran yakni (1) identitas mata pelajaran, (2) rumusan indikator dan tujuan pembelajaran, (3) materi pembelajaran, (4) pemilihan model dan strategi pembelajaran, (5) rancangan kegiatan inti dalam pembelajaran, (6) pemilihan sumber belajar, dan (7) kesesuaian teknik penilaian. Penilaian dilakukan dengan menggunakan skala likert dengan rentang skor minimal 0 hingga 4. Analisis data dilakukan dengan menentukan persentase skor untuk tiap indikator penilaian. Hasil penelitian menunjukkan bahwa supervisi akademik mampu meningkatkan kemampuan guru dalam menyusun Rencana Pelaksanaan Pembelajaran (RPP).
\end{abstract}

Kata Kunci:supervisI akademik, kemampuan merancang, rencana pelaksanaan pembelajaran.

\section{PENDAHULUAN}

Proses pendidikan harus dilakukan secara terencana dengan berbagai pemikiran yang objektif dan rasional, sehingga seluruh potensi peserta didik dapat dikembangkan secara optimal. Kata terencana menunjukkan bahwa betapa pentingnya perencanaan pembelajaran bagi setiap proses pembelajaran.

Pendidikan merupakan aspek penting dalam perkembangan peradaban hidup manusia khususnya manusia di negera Indonesia. melihat pada pentingnya pendidikan dalam peradaban hidup manusia, sosok yang memiliki adab setidak-tidaknya memiliki common sense bahwa pendidikan memiliki peranan yang sangat penting bagi kehidupan manusia (Taufiq, 2014). Indonesia sebagai negara yang masih berkembang seyogianya harus terus berupaya untuk memperbaiki dirinya terutama dalam hal pendidikan. Melalui pendidikan yang berkualitas diharapkan mampu mencetak calon penerus bangsa yang inovatif dan kreatif. Mutu pendidikan dapat ditingkatkan dengan memperbaiki mutu pembelajaran yang merupakan perpaduan antara kegiatan belajar yang dilakukan siswa dengan kegiatan mengajar yang dilakukan guru (Parwati, dkk, 2013).

Penerapan supervisi akademik di sekolah perlu dilakukan dengan sungguh-sungguh dan berkesinambungan. Supervisi yang dilakukan oleh kepala sekolah tersebut diharapkan dapat meningkatkan kemampuan guru dalam melakukan pembelajaran sesuai standar yang berlaku. Pembelajaran yang dilakukan sesuai standar, memberi kesempatan kepada peserta didik untuk belajar secara optimal. Supervisi akademik yang dilakukan dengan baik secara langsung mampu meningkatkan kemampuan seorang guru dalam memperbaiki performa mengajarnya. Begitu juga supervisi akademik secara tidak langsung membantu peserta didik untuk meningkatkan kompetensinya sehingga hasil belajarnya akan baik dan meningkat (Sarimuna, 2019).

Kepala sekolah adalah pemegang kunci keberhasilan keberlangsungan pendidikan di sekolah yang dipimpinnya. Kepala sekolah merupakan leader yang dituntut memiliki 
kemampuan dasar mengkordinasikan dan mengatur setiap kegiatan dan peristiwa di sekolah. Begitu juga kepala sekolah dituntut memiliki kemampuan dalam mensupervisi warga sekolahnya(Jones, 2016). Sebagai sosok yang memiliki peranan penting dalam pendidikan, kepala sekolah bertanggung jawab membantu, membimbing dan mengarahkan guru-guru yang mendapat kesulitan dalam pelaksanaan tugas. Pelaksanaan kegiatan membantu memecahkan permasalahan yang dihadapi guru tersebut dinamakan supervisi. Supervisi yang dilaksanakan kepala sekolah secara efektif danberkelanjutan diharapkan akan memberikan kontribusi yang cukup besar terhadap guru-guru dalam usahanya memperbaiki dan meningkatkan cara kerja mereka dari waktu ke waktu(Hansen, et, al, 2015).

Tak kalah pentingnya dengan kepala sekolah, guru juga merupakan komponen yang memegang peranan dalam bidang pendidikan. Keberhasilan pendidikan lebih banyak ditentukan oleh kemampuan guru dalam melaksanakan tugasnya. Sebagai komponen penting dalam pendidikan di sekolah terdapat 5 tugas pokok yang harus dikerjakan oleh setiap guru, antara lain: (1) menjabarkan isi kurikulum, yaitu tugas guru dalam menyusun perencanaan pembelajaran, seperti menyusun program tahunan, semesteran, mingguan sampai ke program harian; (2) melaksanakan pembelajaran, yakni tugas guru menyampaikan tujuan dan materi pembelajaran, dengan memilih metode, penggunaan alat/media dalam pembelajaran; (3) melaksanakan evaluasi/penilaian; (4) melaksanakan tugas dengan rasa tanggung jawab; (5) melaksanakan disiplin dalam arti luas(Ramadoni, dkk, 2016).

Banyak guru justru tidak memahami peranan siswa sebagai individu yang belajar. Guru lebih banyak memberikan materi kepada siswa dan melaksanakan pembelajaran dengan pendekatan teacher centre (Purwati, dkk, 2016). Kecenderungan siswa yang hanya sebagai penerima informasi disebabkan oleh pembelajaran yang terjadi dengan komunikasi satu arah (Balanay, et, al, 2013). Oleh karena itu, dewasa ini pembelajaran yang terjadi mengalami pergeseran dan diarahkan pada student centre. Oleh karena itu, kompetensi guru dalam merancang pembelajaran dan mengimplementasikan rancangannya di kelas harus semakin ditingkatkan.

Proses pembelajaran harus fokus pada konteks dan pengalaman yang dapat membuat siswa memiliki minat dan dapat melakukan aktivitas belajar. Dengan kata lain kualitas pembelajaran akan sangat dipengaruhi oleh kualitas perencanaan pembelajaran yang digunakan. Perencanaan pembelajaran yang disusun dengan menekankan pada beragam aktivitas yang menuntut siswa untuk lebih banyak terlibat aktif akan memberikan pengaruh terhadap pengalaman belajarnya (Anggraeni, dkk, 2018). Anak yang dilibatkan aktif selama proses pembelajaran akan memiliki banyak pengalaman belajar, sedangkan anak yang selama proses pembelajaran kurang terlibat aktif maka hanya akan memperoleh sedikit pengalaman belajar. Perencanaan pembelajaran didefinisikan sebagai prosedur sistematis di mana program pendidikan dan pelatihan dikembangkan dan disusun dengan tujuan untuk peningkatan pembelajaran yang substansial. Adapun tujuan utama dari perencanaan pembelajaran adalah untuk menunjukkan perencanaan, pengembangan, penilaian dan pengelolaan proses pembelajaran (Isman, 2011). Hal ini menunjukkan betapa pentingnya perencanaan pembelajaran bagi setiap proses pembelajaran.

Tugas guru seperti yang dikemukakan di atas, adalah salah satu tugas diantara tugastugas guru yang lainnya. Belum pantas seseorang itu dikatakan berprofesi guru, bila tugas pokok di atas belum dilaksanakannya dengan baik, sebab hal ini merupakan tugas minimal yang harus dilaksanakan seorang guru. Guru-guru mengharapkan adanya kegiatan supervisi untuk membantu memecahkan permasalahan tersebut. Beberapa permasalahan yang dialami oleh guru adalah (1) kendala dalam menyusun RPP yang baik dan sesuai dengan tuntutan kurikulum 2013, (2) pengembangan strategi pembelajaran yang efisien dan efektif bagi siswa, (3) perancangan dan pembuatan media pembelajaran yang baik untuk menunjang pelaksanaan pembelajaran, dan masalah-masalah teknis lainnya. Rencana Pelaksanaan Pembelajaran (RPP) berfungsi sebagai acuan bagi guru untuk melaksanakan kegiatan belajar-mengajar (kegiatan 
pembelajaran) agar lebih terarah dan berjalan secara efektif dan efisien. Dengan kata lain, RPP ini akan menjadi panduan yang membantu guru mengontrol pelaksanaan pembelajarannya.

Oleh karena itu, Rencana Pelaksanaan Pembelajaran (RPP) hendaknya bersifat luwes (fleksibel) dan memberi kemungkinan bagi guru untuk menyesuaikannya dengan respon siswa dalam proses pembelajaran yang sesungguhnya. Rencana Pelaksanaan Pembelajaran (RPP) yang tersiapkan sebelum mengajar akan mempermudah, memperlancar, dan meningkatkan hasil belajar. Selain itu, Rencana Pelaksanaan Pembelajaran (RPP) yang disusun secara profesional, sistematis, dan berdaya guna, akan memampukan guru untuk melihat, mengamati, menganalisis, dan memprediksi program pembelajaran sebagai kerangka kerja yang logis dan terencana (Zendrato, 2016). dalam menyusun Rencana Pelaksanaan Pembelajaran (RPP), guru membutuhkan pertimbangan yang cukup detil karena hal tersebut melibatkan banyak hal, seperti kemampuan guru, siswa, fasilitas, dsb. Oleh karena itu, Rencana Pelaksanaan Pembelajaran (RPP) harus dipersiapkan dengan matang.

Namun kenyataan yang terjadi di lapangan, terutama di SMA Negeri 1 Tanjung Jabung Barat, masih ada guru yang mengabaikan pelaksanaan tugas pokoknya tersebut. Diantaranya dapat diamati dari:1) Adanya guru yang belum menyusun Rencana Pelaksanaan Pembelajaran (RPP) dan batas pelajaran dengan baik; 2) Banyaknya guru dalam pelaksanaan belajar mengajar belum menggunakan alat/media pembelajaran; 3) Adanya guru yang belum memiliki alat evaluasi/penilaian seperti kumpulan LKS dan bank soal sususan sendiri. Latihan yang dikerjakan siswa kurang terkoreksi dengan baik. Buku nilai belum diisi sesuai ketentuan. Belum terlihat adanya program tindak lanjut dari pelaksanaan evaluasi/penilaian. Hal ini sejalan dengan yang dijelaskan oleh Arman (2017) yang menyatakan bahwa kendala guru dalam menyusun Rencana Pelaksanaan Pembelajaran (RPP) ini disebabkan berbagai macam faktor. Lewat tanya jawab lisan, hal tersebut disebabkan karena terlalu banyak syarat administrasi sehingga untuk mencari jalan yang praktis, informasi yang diterima lewat pendidikan dan pelatihan belum tuntas secara mendalam sehingga pemahaman materi masih mengambang, kesibukan pribadi di luar kedinasan tidak bisa di tinggalkan sehingga tidak ada kesempatan untuk mempelajari sendiri di rumah.

Berdasarkan permasalahan-permasalahan tersebut, berdasarkan pada tingkat urgensinya, maka kendala guru dalam menyusun Rencana Pelaksanaan Pembelajaran (RPP) menjadi paling penting untuk segera diatasi mengingat pentingnya pelaksanaan pembelajaran yang berkualitas. Oleh karena itu, pelaksanaan kegiatan supervisi ini difokuskan untuk mereduksi permasalahan tersebut. Sebagai kepala sekolah penulis menyadari bahwa permasalahan-permasalahan seperti di atas tidak boleh dibiarkan berlarut-larut. Penulis mencoba merenung dan merencanakan tindakan pembinaan yang sering disebut sebagai kegiatan supervisi pendidikan. Penulis akan mencoba meneliti pelaksanaan tindakan yang direncanakan tersebut untuk mengungkapkan sejauh mana peranan supervisi kepala sekolah dapat membantu pelaksanaan tugas pokok guru SMA Negeri 1 Tanjung Jabung Barat dalam merencanakan melaksanakan dan mengevaluasi pembelajaran.

\section{METODE PENELITIAN}

Jenis penelitian ini adalah penelitian tindakan (Action Research) yakni Penelitian Tindakan Sekolah (PTS). Penelitian tindakan merupakan sebuah bentuk penelitian dengan sifat reflektif terhadap tindakan yang telah dilakukan. Proses perbaikan akan terus berjalan selama permasalahan masih belum berhasil diatasi dengan baik. Dalam penelitian ini, penelitian tindakan sekolah dilakukan dengan tahapan yang diadaptasi dari Kemmis, McTaggart, \& Nixon, (2013: 157), yakni perencanaan, tindakan, pengamatan, dan refleksi.

Penelitian tindakan sekolah terdiri dari 2 siklus yakni siklus I dan siklus II. Tiap-tiap siklus dalam penelitian tindakan ini terdiri atastahapan dalam tiap siklusnya berupa: 1) perencanaan, 2) tindakan, dan 3) refleksi. Tanpa menggunakan observasi. 
Penelitian ini dilakukan di SMA Negeri 1 Tanjung Jabung Barat, Provinsi Jambi. Adapun subjek penelitian dalam PTS ini adalah guru yang mengajar di SMA Negeri 1 Tanjung Jabung Barat, adapun sampel yang digunakan yakni 10 orang guru.

Dalam melihat kemampuan guru dalam membuat Rencana Pelaksanaan Pembelajaran (RPP), terdapat 7 aspek yang diamati yakni (1) identitas mata pelajaran, (2) rumusan indikator dan tujuan pembelajaran, (3) materi pembelajaran, (4) pemilihan model dan strategi pembelajaran, (5) rancangan kegiatan inti dalam pembelajaran, (6) pemilihan sumber belajar, dan (7) kesesuaian teknik penilaian. Dari masing-masing aspek yang diamati terdapat indikator penilaian. Aspek identitas mata pelajaran memiliki dua indikator penialain yakni (a) kejelasan dan kelengkapan identitas, dan (b) ketepatan alokasi waktu. Aspek rumusan indikator dan tujuan pembelajaran memiliki satu indikator penilaian yakni kejelasan rumus indikator dan tujuan dengan standar kompetensi (SK) dan kompetensi dasar (KD).

Penilaian dilakukan dengan menggunakan skala likert dengan rentang skor minimal 0 hingga 4. Analisis data dilakukan dengan menentukan persentase skor untuk tiap indikator penilaian. Keberhasilan pemberian perlakuan didasarkan pada persentase penilaian Rencana Pelaksanaan Pembelajaran (RPP) yang telah dibuat oleh guru. Interpretasi persentase skor seperti yang ditunjukkan Tabel 1 (Satriani, 2016).

Tabel 1. Persentase Skor dan Interpretasinya

\begin{tabular}{cl}
\hline \multicolumn{1}{c}{ PersentaseSkor } & Interpretasi \\
\hline $85-100$ & Sangat baik \\
\hline $70-84,9$ & Baik \\
\hline $55-69,9$ & Cukup \\
\hline $46-54,9$ & Kurang \\
\hline $0-45,9$ & KurangSekali \\
\hline
\end{tabular}

\section{HASIL DAN PEMBAHASAN}

Dalam bab ini dipaparkan hasil penelitian tindakan yang dilakukan kepada seluruh guru di SMA Negeri 1 Tanjung Jabung Barat pada semester ganjil pada tahun pelajaran 2018/2019. Penelitian ini dilaksanakan dalam dua siklus. Hasil dari penelitian pada siklus 1 akan menjadi tolak ukur perubahan dan perbaikan yang sesuai terhadap proses dan teknik yang akan diterapkan pada siklus II. Penelitian dilakukan dengan menerapkan supervisi akademis (Sabir, 2018). Proses pelaksanaan supervisi akademik ini melewati tahapan perencanaan, pelaksanaan, penilaian dan pembahasan. Hal ini dilakukan untuk tujuan yakni agar masalah yang terjadi dapat terpecahkan secara maksimal. Adapun hasil kegiatan penelitian dijabarkan sebagai berikut:

Perencanaan, Dalam dunia pendidikan supervisi memegang peranan penting dengan tujuan untuk memastikan keefektivan dan keproduktifitasan program yang dirancang, termasuk program pembelajaran yang dituangkan dalam Rencana Pelaksanaan Pembelajaran (RPP). Peranan utama seorang supervisor adalah sebagai koordinator, menjadi tempat konsultasi, menjadi pemimpin dari anggota kelompoknya serta menjadi evaluator. Kegiatan supervisi ini berguna untuk meningkatkan kecakapan pribadi seorang guru. Supervisi akademik merupakan serangkaian kegiatan yang direncanakan dengan baik dan matang untuk membantu guru dalam mengembangkan kemampuan pengelolaan kegiatan pembelajaran. Pelaksanaan supervisi akademik dilakukan dengan baik dengan perencanaan matang. Dalam penelitian ini, perencaan dilakukan melalui persiapan perangkat supervisi seperti lembar observasi dan lembar penilaian Rencana Pelaksanaan Pembelajaran (RPP).

Pelaksanaan, Supervisi akademik dilaksanakan sesuai dengan schedule yang telah disusun dan disepakati antara kepala sekolah (dalam hal ini sekaligus sebagai peneliti) dengan guru di SMA Negeri 1 Tanjung Jabung Barat. Untuk dapat mencapai tujuan akhir supervisi akademik dengan baik maka diperlukan adanya kesesuaian antara implementasi dengan perencanaan yang telah disusun dengan matang. Pelaksanaan kegiatan supervisi dilakukan 
dengan langkah yakni (1) mengadakan evaluasi terhadap pelaksanaan kurikulum dengan seluruh sarana dan prasarana yang menyertai; (2) membantu serta membina guru dengan melalui kegiatan pemberian petunjuk, arahan, dan pelatihan agar guru dapat meningkatkan keterampilan dan kemampuan mereka dalam melaksanakan proses pembelajaran, dan(3) membantu guru untuk mampu menyelesaikan dengan baik.

Evaluasi, Pada dasarnya evaluasi merupakan proses pemaknaan nilai seorang maupun program dengan menggunakan acuan tertentu untuk dapat mencapai tujuan tertentu. Yang dimaksud dalam evaluasi supervisi akademik ini merupakan proses track keterlaksanaan program dan ketercapaian tujuan. Proses evaluasi dilakukan dengan merefleksikan tingkat keberhasilan guru dalam memecahkan permasalahan, yakni kebingungan guru dalam merancang Rencana Pelaksanaan Pembelajaran (RPP) yang baik. Rencana Pelaksanaan Pembelajaran (RPP) yang baik merupakan langkah awal dalam merancang pembelajaran yang baik. Salah satu tujuan pembelajaran yang harus dicapai adalah pemahaman konsep oleh siswa. Untuk mencapaian tujuan tersebut cukup banyak ditemui kendala oleh guru. Jika rencana pembelajaran tidak dirancang dengan baik, maka akan sulit melaksanakan proses pembelajaran yang dapat berhasil dalam mencapai tujuan. Oleh karena itu, kemampuan dalam membuat Rencana Pelaksanaan Pembelajaran (RPP) yang matang merupakan hal yang perlu dilatihkan pada guru.

\section{Kemampuan Guru dalam Membuat Rencana Pelaksanaan Pembelajaran (RPP)}

Kemampuan guru dalam membuat Rencana Pelaksanaan Pembelajaran (RPP) sesuai dengan persentase skor aspek yang diamati untuk tiap guru SMA Negeri 1 Tanjung Jabung Barat. Adapun persentase skor aspek yang diamati pada masing-masing siklus seperti yang ditunjukkan Tabel 2.

Tabel 2. Persentase Skor Masing-Masing Aspek yang Telah Diamati

\begin{tabular}{llccc}
\hline No & Aspek yang Diamati & \%PraSiklus & $\begin{array}{c}\text { \% Siklus } \\
\text { I }\end{array}$ & $\begin{array}{c}\text { \% Siklus } \\
\text { II }\end{array}$ \\
\hline 1 & Identitasmata pelajaran & 100,00 & 100,00 & 100,00 \\
\hline 2 & Rumusanindikatordantujuanpembelajaran & 60,00 & 81,25 & 93,75 \\
\hline 3 & Materipembelajaran & 65,00 & 85,94 & 95,31 \\
\hline 4 & Pemilihanmodeldanstrategipembelajaran & 80,00 & 87,50 & 92,71 \\
\hline 5 & Rancangankegiataninti dalampembelajaran & 75,00 & 84,38 & 95,31 \\
\hline 6 & Pemilihansumber belajar & 81,67 & 92,71 & 95,83 \\
\hline 7 & Kesesuaianteknikpenilaian & 70,00 & 73,44 & 93,75 \\
\hline
\end{tabular}

Tabel 2 tersebut di atas menunjukkan persentase skor untuk masing-masing aspek yang diamati pada tiap siklus. Berdasarkan data tersebut terlihat bahwa aspek identitas mata pelajaran sudah menunjukkan skor maskimal dari pada siklus, siklus I, dan siklus II. Sebelum pelaksanaan tindakan, skor guru yang paling rendah adalah pada aspek rumusan indikator dan tujuan pembelajaran yang hanya memperoleh skor 60. Artinya, sebelum penelitian dilakukan guru masih mengalami kebingungan dalam merumuskan indikator dan tujuan pembelajaran yang benar. Secara keseluruhan, seluruh aspek menunjukkan adannya peningkatan pada tiap siklusnya. Selain persentase skor untuk tiap aspek yang diamati, Tabel 3 berikut menyajikan data persentase skor tiap guru pada masing-masing siklus.

Tabel 3. Persentase Skor

\begin{tabular}{lccc}
\hline \multirow{2}{*}{ Guru } & \multicolumn{3}{c}{ Rata-Rata } \\
\cline { 2 - 4 } & PraSiklus & Siklus I & Siklus II \\
\hline Guru 1 & 80,00 & 88,33 & 93,33 \\
\hline Guru 2 & 76,67 & 78,33 & 90,00 \\
\hline Guru 3 & 78,33 & 91,67 & 98,33 \\
\hline Guru 4 & 78,33 & 86,67 & 96,67 \\
\hline
\end{tabular}




\begin{tabular}{llll}
\hline Guru 5 & 78,33 & 91,67 & 95,00 \\
\hline Guru 6 & 75,00 & 85,00 & 96,67 \\
\hline Guru 7 & 73,33 & 86,67 & 96,67 \\
\hline Guru 8 & 78,33 & 90,00 & 95,00 \\
\hline Guru 9 & 75,00 & 85,00 & 96,67 \\
\hline Guru 10 & 76,67 & 78,33 & 90,00 \\
\hline
\end{tabular}

Seperti yang ditunjukkan Tabel 3, terlihat bahwa secara keseluruhan kemampuan guruguru SMA Negeri 1 Tanjung Jabung Barat dalam merancang Rencana Pelaksanaan Pembelajaran (RPP) sudah menunjukkan adanya progres/peningkatan. Masing-masing guru dalam membuat Rencana Pelaksanaan Pembelajaran (RPP) sudah dalam kategori baik. Kendati demikian, masih ada beberapa koreksi pada poin krusial yang penting dan perlu untuk direvisi. Secara keseluruhan peningkatan persentase skor pada tiap siklus seperti yang ditunjukkan Gambar 1.

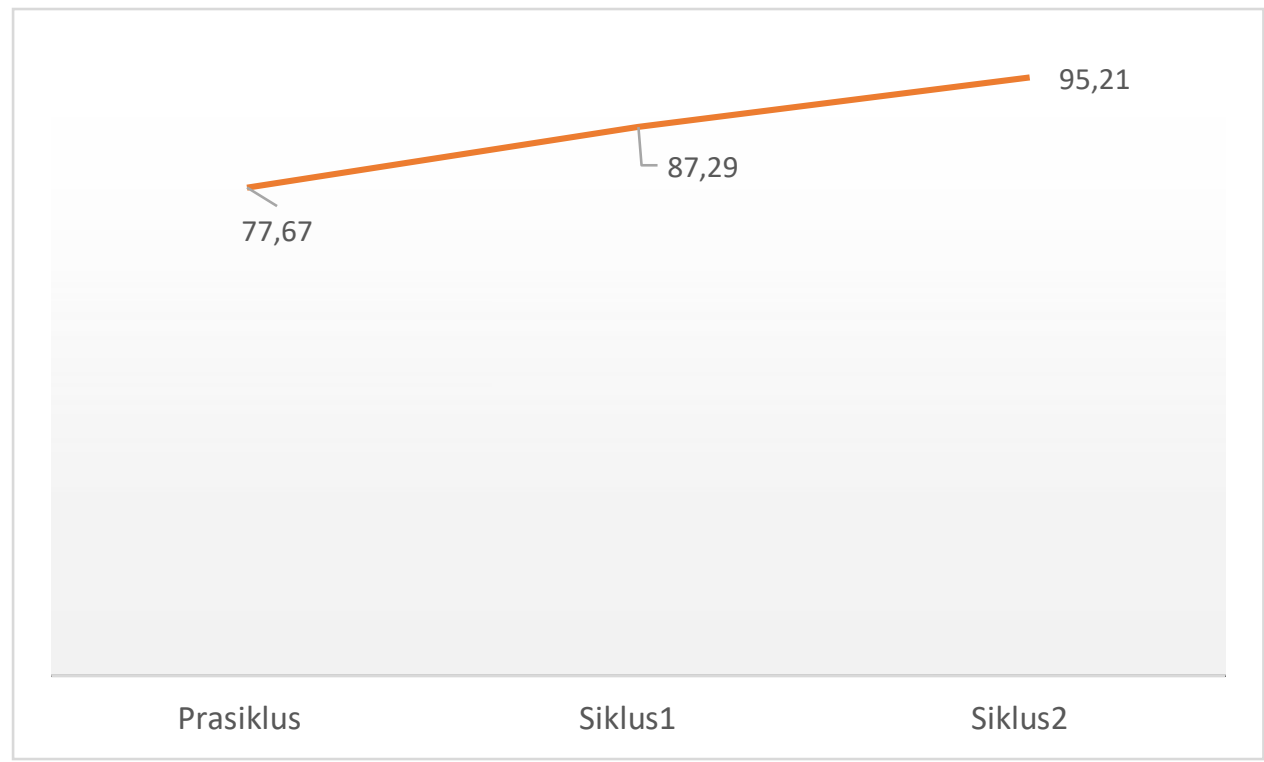

Gambar 1. Peningkatan Persentase Rata-Rata Skor

Berdasarkan Gambar 1 terlihat bahwa rata-rata persentase skor pada pra siklus adalah 77,67. Pada siklus I kemudian meningkat menjadi 87,29 dan pada siklus II meningkat menjadi 95,21. Jika dilihat dari kategori kemampuan, kemampuan guru SMA Negeri 1 Tanjung Jabung Barat pada pra siklus dalam kategori baik sedangkan pada siklus I dan siklus II dalam kategori sangat baik. Hasil tersebut menunjukkan bahwa supervisi akademik yang dilakukan oleh kepala sekolah menunjukkan hasil positif dalam meningkatkan kemampuan guru dalam merancang Rencana Pelaksanaan Pembelajaran (RPP). Hal tersebut tentu baik, terutama dalam menjalankan salah satu peran kepala sekolah. Sudah seharusnya kepala sekolah menyusun program supervisi untuk memberikan bantuan kepada guru (Maralih, 2014). Bahkan pada negara maju sekalipun, proses semacam ini masih dianggap penting demi perbaikan mutu pendidikan yang berkelanjutan (Hadi, 1995). Supervisi akademik oleh kepala sekolah memiliki pengaruh yang signifikan terhadap mutu pendidikan melalui peningkatan profesionalisme guru (Suwartini, 2017).

Guru SMA Negeri 1 Tanjung Jabung Barat hendaknya terus dan selalu berkarya agar dapat meningkatkan kualitas pendidikan. Lebih khusus pada aspek pengembangan profesionalisme guru untuk meng-upgrade pengetahuan dan keterampulan mereka. Kedepannya hendaknya proses supervisi akademik ini dilakukan secara berkesinambungan. Tidak hanya difokuskan pada kemampaun guru dalam merancang Rencana Pelaksanaan Pembelajaran (RPP), namun pada aspek-aspek lain. 


\section{KESIMPULAN}

Hasil penelitian menunjukkan bahwa supervisi akademik mampu meningkatkan kemampuan guru SMA Negeri 1 Tanjung Jabung Barat dalam menyusun Rencana Pelaksanaan Pembelajaran (RPP). Rata-rata persentase skor pada pra siklus adalah 77,67 meningkat menjadi menjadi 87,29 pada siklus I dan pada Siklus II meningkat menjadi 95,21. Jika dilihat dari kategori kemampuan, kemampuan guru pada pra siklus dalam kategori baik sedangkan pada siklus I dan siklus II dalam kategori sangat baik.

Pelaksanaan supervisi akademik ini merupakan hal yang baik dalam meningkatkan kemampuan guru SMA Negeri 1 Tanjung Jabung Barat yang dapat bermuara pada perbaikan proses pembelajaran. Oleh karena itu, diharapkan kegiatan semacam ini dapat dilakukan oleh kepala sekolah maupun pengawas sekolah.

\section{DAFTAR PUSTAKA}

Anggraeni, P., \& Akbar, A. (2017). Kesesuaian rencana pelaksanaan pembelajaran dan proses pembelajaran. Jurnal Pesona Dasar, 6(2).

Arman, A. (2017). Upaya peningkatan kompetensi guru dalam menyusun rencana pelaksanaan pembelajaran melalui supervisi akademik Kepala Sekolah di SMAN 1 Lembah Melintang Kabupaten Pasaman Barat. Jurnal Manajemen Pendidikan, 1(1).

Balanay, C. A. S., \& Roa, E. C. (2013). Assessment on students' science process skills: A student-centred approach. International Journal of Biology Education, 3(1).

Hansen, B., \& Lárusdóttir, S. H. (2015). Instructional leadership in compulsory schools in Iceland and the role of school principals. Scandinavian Journal of Educational Research, 59(5), 583-603.

Isman, A. (2011). Instructional Design in Education: New Model. Turkish Online Journal of Educational Technology - TOJET, 10(1), 136-142

Jones, M. (2016). Supervision, learning and transformative practices. In Social work, critical reflection and the learning organization (pp. 21-32). Routledge.

Kemmis, S., McTaggart, R., \& Nixon, R. (2013). The action research planner: Doing critical participatory action research. Springer Science \& Business Media.

Parwati, N. N., Parmiti, D. P., \& Jampel, I. N. (2013). Penerapan pembelajaran picture and picture berbantuan media kartu angka bergambar dapat meningkatkan perkembangan kognitif. Jurnal Pendidikan Anak Usia Dini Undiksha, 1(1).

Purwati, R., Prayitno, B. A., \& Sari, D. P. (2016). Penerapan model pembelajaran inkuiri terbimbing pada materi sistem ekskresi kulit untuk meningkatkan keterampilan pelaksanaan sains siswa kelas XI SMA. In Proceeding Biology Education Conference (Vol. 13, No. 1, pp. 325-329).

Ramadoni, W., Kusmintardjo, K., \& Arifin, I. (2016). Kepemimpinan Kepala Sekolah dalam Upaya Peningkatan Kinerja Guru (Studi Multi Kasus di Paud Islam Sabilillah dan SDN Tanjungsari 1 Kabupaten Sidoarjo). Jurnal Pendidikan: Teori, Penelitian, Dan Pengembangan, 1(8), 1500-1504.

Sabir, M. (2018). Supervisi Akadamik terhadap Peningkatan Kompetensi Pedagogik Guru Madrasah Ibtidaiyah (Penelitian Tindakan Pada Guru Madrasah Ibtidaiyah di Kab. Tana Toraja). Istiqra, 6(1), 16-25.

Sarimuna, L. (2017, December). Upaya Meningkatkan Kemampuan Guru dalam Menerapkan Metode Kooperatif Learning Tipe STAD pada Pembelajaran Kewirausahaan Kelas XI Sekolah Binaan melalui Workshop di MGMP (Penelitian Tindakan Sekolah). In Forum Ilmu Sosial (Vol. 46, No. 2, pp. 165-179).

Taufiq, A. (2014). Hakikat Pendidikan di Sekolah Dasar. In Pendidikan Anak Di SD (p. 1.3). Jakarta: Universitas Terbuka. Retrieved from http://www.pustaka.ut.ac.id/lib/wpcontent/uploads/pdfmk/PDGK4403-M1.pdf 
Zendrato, J. (2016). Tingkat penerapan rencana pelaksanaan pembelajaran dalam pelaksanaan pembelajaran di kelas suatu studi kasus di SMA Dian Harapan Jakarta. Scholaria: Jurnal Pendidikan Dan Kebudayaan, 6(2), 58-73. 